\title{
Microbial Ecological Dynamics, Load and Diversity of Sculptured Artworks in Cross River University of Technology Outdoor Gallary
}

\author{
Etim, Lawrence Bassey* \\ Department of Microbiology, Cross River University of Technology, Calabar, Nigeria \\ *Corresponding author
}

\section{A B S T R A C T}

Keywords

Outdoor, Sculpture,

Gallery, Ecology, Microbial, Diversity

Article Info

Accepted:

18 September 2019

Available Online:

10 October 2019
The microbial ecology of an outdoor artwork gallery was evaluated using basic microbiological standardize techniques. The sculptures made up of wood, cement and cast metal had a mean heterotrophic bacterial count of; wood $\left(3.2 \times 10^{4}\right)$, cement $\left(4.3 \times 10^{4}\right)$ and metal $\left(2.5 \times 10^{4}\right)$ while the fungal count were wood $\left(4.6 \times 10^{4}\right)$, cement $\left(2.7 \times 10^{4}\right)$ and metal $\left(1.8 \times 10^{4}\right)$ colonies forming unit per milliliter of the scrapped solutions. The eight (8) bacterial genera and their frequency of occurrence obtained were; Bacillus sp (75\%), Pseudomonas sp (74.3\%), Enterobacter sp (71.4\%), Micrococcus sp (67.1\%), Flavobacterium sp (54.3\%), Acinobacter sp (51.1\%), Sarcina sp (50\%) and Cyanobacterium sp (32.9\%). The eight fungal genera obtained were: Aspergillus sp (97.1\%), Penicillium sp (87.1\%), Fusarium sp (78.6\%), Cryptococcus sp (68.6\%), Rhizopus sp (62.9\%), Alternaria sp (58.6\%), Mold sp (52.9\%) and yeast (45.7\%). Statistically, there was no significant $(\mathrm{p}>0.05)$ difference between the bacterial and fungal occurrence. However, a significant $(\mathrm{p}>0.05)$ difference was observed among the sculptured materials: for bacteria; cement $>$ wood > metal while for fungi; wood > cement $>$ metal. The enhanced colonization rate and growth of the microbial isolates correlated $(r=0.01)$ positively to the sampled materials as substrates, physicochemical properties of the study site and the presence of the cations and anions as means of electron transport. The presence of these species of bacteria and fungi promote serious deterioration problems to the aesthetic values of these sculptures. Therefore, empirical study targeting the control and preservation of these artworks with natural and environmentally friendly materials is suggested.

\section{Introduction}

Art in form of sculpture are primarily developed for aesthetic beautification of environment and documentation of history (Urzi, 2001). The constant exposure of artwork in urban public outdoor galleries is a risk to environmental hazardous element. This includes climatic pollution and biological agent with a reluctant role in the deterioration cultural heritage aesthetic values (Ameotral, 2012).

The biodeterioration of these sculptures and other artifacts is the result of interaction between living organisms especially 
microorganisms, materials and environmental condition (Capadicasa et al., 2010). Therefore the growth of microorganisms on artworks involved into main factors, the chemical composition of the object and the environmental factors (Lopez-miras et al., 2013).

Fungi involved in biodeterioration represent the group of chemoheterotrophs characterized by the presence unicellular or multicellular hyphae and are metabolically versatile (Pinar et al., 2013). The most diverse species of fungi associated with deterioration of artwork are: Alteruaria, Clasdosporium, Sarcromyces, Peuicillium, ASpergillus, Acremorium, Oidiodendron, Gloeophyllum and Phialophora. The fungi versatility allows them to colonize on a wide range of substrates such as wood, limestone and metal enhanced by extreme environmental condition and the mutualistic association with cyanobacterium and algae (Pinor et al., 2011; Dakal and Cametro, 2012).

The heterotrophic bacterial species that colonize environmentally exposed artworks nutritionally belongs to three groups; photoautotroph, chemolithoautotrophs and chemorganistroph. Among the phototrophs and chemorganistrophs are the cyanobacterial sulphoxidizing and nitrifying bacteria (Dakal and Camotro, 2012). These bacteria genera include; Alcalegenes, Bacillus, Pseudomonas, Flavobacterium, Micrococcus, Sarcina, Mycobacterium Streptomyces, Staphylococus, Arsthrobacter, and Paenibacillus (Jurado et al., 2012, Ertenauer et al., 2013). These groups of bacteria known for their simple nutritional and ecological needs developed, proliferate and colonized monument faster than other groups. They are responsible for the irreversible damage to major artwork, sculpture and monuments. Among them cyanobacterium have the ability to survive under the condition of repeated drying and rehydration occurring on exposed artwork surfaces and to protect themselves from harmful ultraviolet (UV) radiation by synthesizing protective pigments (Rispim et al., 2003).

Environmental physiochemical factors that enhanced colorization of microorganism on artwork and monument includes; Temperature, composition of the material, pollutants, humility, light and wind (Nuhoglulet et al., 2006; Lan et al., 2010). High relative humility in the air and high temperature provides moisture needed to encourage deteriorating chemical reaction and microbial growth. Light accelerates both cumulative and irreversible deterioration of artwork and monument (Grossi et al., 2006). Pollutants in the air contribute significantly to the deterioration of archival artwork. The atmosphere contains lots of pollutants of different origin. Persistent air pollutants of industrial cities like oxides, sulphur, nitrogen, and some carbonaceous particles, ash and other particulate matter upon setting on the surface of the artwork, destroy their aesthetic and artistic beauty (Nuhuglu et al., 2006). This research work, therefore aimed at investigating and establishing the microbial dynamics of exposed outdoor artwork in Cross River State University of Technology and to suggest empirical measure to control their menace.

\section{Materials and Methods}

\section{Sample selection}

Sculptured status of three years old, made out of wood, cement stone and metal were selected for the microbial investigation. The materials chosen had been exposed to both physical and bio-weathering conditions within this period. The study was conducted between the transitional period of the year between the setting of the wet months and the onset of the 
dry months. This period of the year is characterized by minimum rainfall, ambient temperature, low moisture, adequate sunshine and wind.

\section{Sample collection and microbial isolation}

The method described by Cheesbrough (2000) and earlier adopted by () was used. The various objects selected were swapped with sterile swap sticks and spatula. The swapped materials and particles collected from respected objects were aseptically put in $50 \mathrm{mLtryptophane}$ broth supplemented with physiological saline $(0.8 \% \mathrm{w} / \mathrm{v})$ solution in a $100 \mathrm{~mL}$ capacity sterile flasks. Then transported in an ice-packed cooler to the laboratory for analysis and microbial assay.

\section{Determination of the physicochemical properties of the sculptured materials}

The physical and qualitative chemical properties of the gallery were determined as described by Anne (2019).

The $\mathrm{pH}$ of the swapped solution was measured with a $\mathrm{pH}$ meter (SANXON PHB-3 pH meter, China and Jenway)

Mean temperature of the air circulation around the gallery side was taken by hanging the thermometer in strategic position within the site for morning, afternoon and evening.

The amount of moisture in the air was equally determined with a moisture strip () placed around the objects.

The qualitative presence of the cations and anions in the sampled object were determined as described by APHA (1998).

Procedures for each of the ions were adopted accordingly by Royal society of chemistry; www.rse.org (downloaded) and wired chemist: www.wiredchemist.com > chemistry. Traces of the ions per sample were considered as being present and or not present after treatment with:

$\mathrm{Fe}^{3+}$ precipitated (ppt) in $0.1 \mathrm{M} \mathrm{H}_{2} \mathrm{~s}$ solution at pH 9.

$\mathrm{Ca}^{2+}, \mathrm{k}^{+}, \mathrm{Na}^{+}$ppt in $0.2 \mathrm{M}(\mathrm{NH} 4)_{2} \mathrm{CO}_{3}$ at $\mathrm{pH}$ 10 while other ions were soluble

$\mathrm{NO}_{3}^{-}, \mathrm{PO}_{4}{ }^{3-}, \mathrm{CO}_{3}^{-}, \mathrm{SO}_{4}{ }^{2-}$ ppt in $0.1 \mathrm{M} \mathrm{H}_{2} \mathrm{~S}$ at pH 5.

\section{Bacterial isolation, heterotrophic load and identification}

The sample for bacterial isolation was cultured on nutrient agar (brand) supplemented with a combination of a broad spectrum antibiotic to inhibit the growth of fungal contaminants as described by ().

A ten-fold serial dilution of the sample was made and $1.0 \mathrm{~mL}$ of $10^{-4}$ diluents was spread plated in triplicate. The plates were incubated at room temperature $\left(28 \pm 2^{\circ} \mathrm{C}\right)$ for $18 \mathrm{~h}$. The heterotrophic colonies were counted and recorded as $\mathrm{CFUmL}^{-1}$ of the representative samples. Discrete colonies were picked and subcultured on MaConkey, sorbitol, etc for growth. Then bacterial isolates obtained were identified based on their; Cultural and morphological growth characteristics, Gram reaction, biochemical and sugar fermentation properties as described by Cooke (1987).

Fungal isolation, heterotrophic load and identification

The method described by () was adopted. The samples were respectively cultured on potato dextrose agar (brand name) fortified with antibacterial agent (chloramphenicol/ streptomycin) to inhibit the growth of bacterial contaminants. A ten-fold serial dilution of the sample was made and $1.0 \mathrm{~mL}$ of $10-4$ diluents was aseptically spread plated in triplicates. Then the plates were incubated at room 
temperature $\left(28 \pm 2^{0} \mathrm{C}\right)$ for $72 \mathrm{~h}$. The mixed colonies developed were counted and recorded as colony forming units $\left(\mathrm{CFUmL}^{-1}\right)$ per millilitre of the representative samples.

Discrete colonies were picked and subcultured on Sabouraud agar (brand name) and Rose Bengal agar for confirmed growth and characterization. The obtained isolates were identified on the basis of their cultural, microscopic and morphological examination and characterization of colony colour, pigments, types of hyphae, aerial hyphae, substrate hyphae, mycelium, asexual and sexual spores conidiospores and sporangiospores as described by Barnett and Hunter (1998).

\section{Statistical analysis}

Data collected were analyzed using IBM SPSS statistic version 20 (IBM corporation, 2011). Simple means, percentages and frequencies were computed. Also means were computed using Analysis of variance (ANOVA) to determined associations.

\section{Results and Discussion}

Table 1 shows the qualitative ecological biophysicochemical parameters of the three samples. The temperature was seen to fluctuate between $28^{\circ} \mathrm{C}$ to $30^{\circ} \mathrm{C}$. The atmospheric moisture and $\mathrm{pH}$ of the objects were considered low, moderate and high with no tangent difference. The cations $\left(\mathrm{Na}^{+}, \mathrm{K}^{+}\right.$, $\mathrm{Cu}^{2+}$, and $\left.\mathrm{Ca}_{2}{ }^{+}\right)$and anions $\left(\mathrm{NO}_{3}{ }^{-}, \mathrm{CO}_{3}{ }^{-}, \mathrm{PO}_{4}{ }^{3-}\right.$ , and $\mathrm{SO}_{4}{ }^{2-}$ ) were qualitatively considered as being absent (Nil) or present. The metal objects were of cast materials that were made of little or no quantified cations and anions composition. However cement based sculptures contained more of the cations and anions than metal and wood.

Table 2 shows the total heterotrophic bacterial and fungal contaminants count per sample material. The wood sample had the highest fungal load $\left(4.6 \times 10^{4}\right)$ while the cement base sample had the highest bacterial load $(4.3 \mathrm{x}$ $\left.10^{4}\right)$.

The total bacterial count from all the samples was $10.0 \times 10^{4} \mathrm{CfumL}^{-1}$ more than fungal load of $9.1 \times 10^{4} \mathrm{CfumL}^{-1}$. Similarly, the metal sample had the lowest bacterial count $\left(2.5 \times 104 \mathrm{CfumL}^{-1}\right)$ and fungal count $\left(1.8 \times 10^{4}\right.$ CfumL $^{-1}$ ) with no significant difference in the load of both bacterial and fungal counts.

Table 3 indicates the bacterial contaminant isolated and their frequency of occurrence from each sample. Eight (8) bacterial genera were isolated and Bacillus sp (75.7\%) was the most isolated contaminant followed by Pseudomonas sp (74.3\%) while Cyanobacterium $\mathrm{sp}$ was the least isolated with a frequency of $32.9 \%$. However, Enterobacter sp was not isolated from cement, Flavobacterium $s p$ from wood and Sarcina $\mathrm{sp}$ from metal (Table 4).

Table 5 shows the distribution and frequency of bacterial isolates from the three samples. High prevalence of Bacillus sp (50\%), Pseudomonas sp (38.2\%) and Micrococcus sp $(19.3 \%)$ were observed with a significant $(\mathrm{p}<0.5)$ difference to Enterobacter sp $(4.9 \%)$, Acinetobacte rsp (6\%) and Sarcina sp (6\%). Cyanobacterium sp (8\%), Flavobacterium sp (4.5\%). Table 6 shows the distribution and frequency of fungal isolates in the three sampled materials. Aspergillu ssp (37.8\%), Penicillium sp (30.2\%) and Fusarium $s p$ $(30.7 \%)$ were observed with a prevalence significantly $(\mathrm{p}>0.5)$ difference to Alternaria sp (17.6\%), Rhizopus sp (14.3\%), Mold sp (11.1\%), Yeast $(4.9 \%)$ and Cryptococcus $s p$ (3.8\%).To be continued

The biophysicochemical nature of the gallery is considered as a conducive condition for 
enhance microbial growth. The presence of adequate moisture (humidity), temperature and $\mathrm{pH}$ promote the high ecological microbial diversity and heterotrophic number of the isolates. In a similar study Etim and Antai (2014) demonstrated that adequate $\mathrm{pH}$ and temperature encourage the growth and colonization of bacteria and fungi in painted art objects. Therefore, the high microbial load and diversity is considered a consequence of these environmental conditions as different cells exhibit different response to changes in temperature and $\mathrm{pH}$.

The presence of the cations and anions as part of the sample composition in contact with the moderate moisture enhances the growth, diversity and subsequent colonization of the sculptures. The sources of these ions are considered a function of both anthropogenic and bio-weathering activities. Haavisto (2002) and Luciana et al., (2004) has opined that metals and heavy metals had increased rapidly as a result of metal contamination in soil, waste treatment plant and wood impregnation plants. Secondly, these ions $\left(\mathrm{K}^{+}, \mathrm{Na}^{+}, \mathrm{Fe}^{3+}\right.$, $\left.\mathrm{Ca}^{2+}, \quad \mathrm{Cu}^{2+}, \quad \mathrm{NO}_{3}^{-}, \mathrm{SO}_{4}^{2-}, \mathrm{CO}_{3}^{-}\right)$in the environment play an integral role in the life processes of these microbial isolates. Bruins et al., (2000) had suggested that these ions serve as essential micronutrients to microorganisms. The author submitted that ions are used for redox processes, molecules stability through electrostatic interactions, as components of various enzymes and for the regulation of osmotic pressure. This result therefore in concert with the above information, shows that the high bacterial and fungal heterotrophic load, speciation and frequencies of occurrences to a larger extend had been a factor of the ecological parameters of the exposed gallery and the composition of the sculpture materials.

The high numbers of heterotrophic bacterial and fungal count is considered the effect of substrate composition. The wood with a high cellulolistic organic matter had high of fungi $\left(4.6 \times 10^{4} \mathrm{CfumL}^{-1}\right)$ than bacteria $\left(3.2 \times 10^{4}\right.$ $\mathrm{mL}^{-1}$ ) the bacterial load appeared higher in the cement based sculptures than fungal load of $\left(2.7 \times 10^{4} \mathrm{CfumL}^{-1}\right)$. Similarly, the metal works had more bacterial load $\left(2.5 \times 10^{4} \mathrm{CfumL}^{-1}\right)$ than fungi $\left(1.8 \times 10^{4} \mathrm{CfumL}^{-1}\right)$.

Table.1 shows some biophysicochemical properties of the samples.

\begin{tabular}{|l|c|c|c|}
\hline Parameters & Wood & Cement & Metal \\
\hline Temperature & $28 \pm 3^{\circ} \mathbf{C}$ & $29 \pm 1^{\circ} \mathbf{C}$ & $30 \pm 2^{\circ} \mathrm{C}$ \\
Moisture & Moderate & High & Moderate \\
$\mathbf{p H}$ & High & High & Low \\
$\mathbf{N a}^{+}$ & Nil & Present & Nil \\
$\mathbf{K}^{+}$ & Nil & Low & Low \\
$\mathbf{N O}_{3}{ }^{-}$ & Present & Present & Present \\
$\mathbf{P O}_{4}{ }^{3-}$ & Present & Present & Present \\
$\mathbf{C O}_{3}{ }^{-}$ & Nil & Present & Nil \\
$\mathbf{C a}^{2+}$ & Nil & Present & Nil \\
$\mathbf{S O}_{4}{ }^{2-}$ & Present & Present & Nil \\
$\mathbf{C u}^{2+}$ & Nil & Nil & Present \\
\hline
\end{tabular}


Table.2 Mean total heterotrophic count for bacteria and fungi per sample material.

\begin{tabular}{|c|c|c|c|}
\hline Sample material & $\begin{array}{l}\text { Sample size } \\
(\mathrm{n}=70)\end{array}$ & $\begin{array}{l}\text { Bacterial isolates } \\
\left.\text { (cfumL }^{-1}\right)\end{array}$ & $\begin{array}{l}\text { Fungal isolates } \\
\left(\text { cfumL }^{-1}\right)\end{array}$ \\
\hline $\begin{array}{l}\text { Wood } \\
\text { Cement base } \\
\text { Metal } \\
\text { Total }\end{array}$ & $\begin{array}{l}25 \\
30 \\
15 \\
70\end{array}$ & $\begin{array}{l}4.3 \times 10^{4.2 \times 10^{4}} \\
2.5 \times 10^{4}\end{array}$ & $\begin{array}{l}4.6 \times 10^{4} \\
2.7 \times 10^{4} \\
1.8 \times 10^{4}\end{array}$ \\
\hline
\end{tabular}

Table.3 Frequency of bacterial isolates in wood, cement and metal samples.

\begin{tabular}{|l|l|l|}
\hline Bacterial isolates & No. of sample $\mathbf{( N = 7 0 )}$ & $\begin{array}{l}\text { Frequency of occurrence } \\
(\%)\end{array}$ \\
\hline Pseudomonas sp & 52 & 74.3 \\
Enterobacter sp & 50 & 71.4 \\
Acinetobacter sp & 40 & 51.1 \\
Bacillus sp & 53 & 75.7 \\
Micrococcus sp & 47 & 67.1 \\
Flavobacterium sp & 38 & 54.3 \\
Cyanobacterium sp & 23 & 32.9 \\
Sarcina sp & 35 & 50.0 \\
\hline
\end{tabular}

Table.4 Frequency of fungal isolates in wood, cement and metal samples

\begin{tabular}{|l|c|c|}
\hline Fungal isolates & No. of sample (N=70) & Frequency of occurrence $(\%)$ \\
\hline Aspergillus sp & 68 & 97.1 \\
Penicillium sp & 61 & 87.1 \\
Fusarium sp & 55 & 78.6 \\
Cryptococcus sp & 48 & 68.6 \\
Rhizopus sp & 44 & 62.9 \\
Alternaria sp & 41 & 58.6 \\
Mold sp & 37 & 52.9 \\
Yeast sp & 32 & 45.7 \\
\hline
\end{tabular}

Table.5 Distribution and frequency of bacterial species from different sample materials

\begin{tabular}{|l|c|c|c|c|}
\hline \multirow{2}{*}{ Bacterial species } & \multicolumn{4}{|c|}{ Collection site/sample } \\
\cline { 2 - 5 } & Wood $(\mathrm{n}=25)$ & Cement(n=30) & Metal(n=15) & Total(n=70) \\
\hline Bacillus $\boldsymbol{s p}$ & $15(60)$ & $13(43.3)$ & $7(46.7)$ & $45(50)$ \\
Pseudomonas $\boldsymbol{s p}$ & $12(48)$ & $8(26.7)$ & $6(40)$ & $26(38.2)$ \\
Enterobacter $\boldsymbol{s} \boldsymbol{p}$ & $2(8.0)$ & $0(0.0)$ & $1(6.7)$ & $3(4.9)$ \\
Acinetobacter $\boldsymbol{s p}$ & $2(8.0)$ & $1(3.3)$ & $1(6.7)$ & $4(6.0)$ \\
Micrococcus $\boldsymbol{s} \boldsymbol{p}$ & $7(28)$ & $5(16.7)$ & $2(13.3)$ & $14(19.3)$ \\
Flavobacterium $\boldsymbol{s p}$ & $0(0.0)$ & $2(6.7)$ & $1(6.7)$ & $3(4.5)$ \\
Sarcina $\boldsymbol{s p}$ & $2(8.0)$ & $3(10)$ & $0(0.0)$ & $5(6.0)$ \\
Cyanobacterium $\boldsymbol{s p}$ & $1(4.0)$ & $4(13.3)$ & $1(6.7)$ & $6(8.0)$ \\
\hline
\end{tabular}


Table.6 Distribution and frequency of fungal species from different sample materials

\begin{tabular}{|l|c|c|c|c|}
\hline \multirow{2}{*}{ Fungal species } & \multicolumn{4}{|c|}{ Collection site/ sample material } \\
\cline { 2 - 5 } & Wood $(\mathrm{n}=25)$ & Cement $(\mathrm{n}=30)$ & Metal(n=15) & Total(n=70) \\
\hline Aspergillussp & $10(40)$ & $12(40)$ & $5(33.3)$ & $27(37.8)$ \\
Penicillin $\boldsymbol{s p}$ & $6(24)$ & $8(26.7)$ & $6(40)$ & $20(30.2)$ \\
Fusariumsp & $8(32)$ & $6(20)$ & $6(40)$ & $20(30.7)$ \\
Cryptococcus sp & $2(8.0)$ & $1(3.3)$ & $0(0.0)$ & $3(3.8)$ \\
Rhizopussp & $5(20)$ & $3(10)$ & $2(13.3)$ & $10(14.3)$ \\
Alternariasp & $4(16)$ & $5(16.7)$ & $3(20)$ & $12(17.6)$ \\
Mold sp & $5(20)$ & $2(6.7)$ & $1(6.7)$ & $8(11.1)$ \\
Yeast sp & $2(8.0)$ & $0(0.0)$ & $1(6.7)$ & $3(4.9)$ \\
\hline
\end{tabular}

The bacteria speciation showed that Bacillus (75.7\%) dominated the artworks, followed closely by Pseudomonas sp (74.3\%) and Enterobacter sp (71.4\%). However, their differences were not statistically significant ( $>0.05$ ) compared to those with a percentage frequencies less than $70 \%$. A report similar to this study had acknowledge that Pseudomonas sp, Bacillus sp, Micrococcus sp and Enterobacter sp are soil and organic waste borne bacteria. Their high incidence of occurrence could be attributed to their exposure to human and the inanimate objects considered in this study (Sterflinger and Pinar, 2013), (Duan et al., 2017).

\section{References}

Anne, M,H.(2019). Qualitative analysis in chemistry; identifying anions and cations http://www.thougthco.com.

APHA (1998). Standard Methods for Examination of Water and Wastewater (20 ${ }^{\text {th }}$ edition). American Public Health Association.

Capadicasa, S. Fedi, S, Porcelli, A.M Zannoni D. (2010). The microbial community dwelling on a biodeteriorated $16^{\text {th }}$ century painting. International Journal of Biodeteriorated and Biodegredation 64(8):727-733

Cripsim C. A., Gaylarde, P.M Gaylade C.C (2003). Algal and cyanobacterial bio film on calcareous histonic building. Current Microbiology. 49(1): 1-9

Dakal, T. C and Cameotra, S.S (2011). Geomicrobiology of cultural momentum and artworks: mechanism of biodeterioration bioconservation strategies and applied molecular approaches. In bioremediation: biotechnology engineering and environment management Ed by Mason, A.C New York: Nova science publisher 66-81 pp.

Dakal, T. C and Cameotra, S.S 9(2012). Microbially induced deterioration if architectural heritage: route and mechanism involved. Environmental sciences Europe 24:36.

Etim and Antai (2014). The effect of temperature and $\mathrm{pH}$ on bacterial degradation of latex paint in humid environment. Global Journal of Pure and Applied Science, 20: 89-94

Ettenauer J., Pinar, G. Sterflinger, K, Gonzalis-Minoz, M.T and Jroundi, F (2011). Melecular monitoring of the microbial dynamics occurring on historical limestone building during and after the in situ application of different bio-consolidation treatment science in total environment. 409(24): 5337-5352.

Haavisto, T, (2002). Contaminated sites in Finland-Queview 2001. The Finnish Environment Services, Helsinki, Finland. 
Jurado, V. Miller A.Z. Alias-Villegas, C. and Laizx., L. (2012). Rubrocter Bracarensis sp. Nov., a novel member of the genus Rubrobacter isolated from a biodeteriorated momentum. Systemic Applied Microbiology 35:306-309

Lan, W.S Li, H,. Wang, W.D. Katayama Y., $\mathrm{Gu}$ J.D. (2010). Microbial community analysis of fresh and old microbial bio film on Bayon temple sandstone of Angkar thom, Cambodia. Microbial Ecology 609(1). 105-115.

Lopez-Miras, M. Pinar G. Romero_ Noguera J. Boliver Galiano, F.C and MartinSanchez I (2013). Microbial communities adhering to the observe and reverse sides of an oil painting on canvas: identification and evaluation of their biodegradative potential. Aerobiology; 29: 301-314.

Nuhuglu, Y. Oguz, E, Ulsu, H Ozbek, A, Ipkoglu, B. Okak I. and Hasenkaglu I
(2006). The accelerating effects of stone monuments under air pollution and continental cold climate condition in Erzurum Turkey. Science to environment 364:272-283.

Royal Society of Chemistry (2019). www.rse.org (downloaded)

Urzi, C., Brusehi, L Salamone, P., Sorlini,C. Stachebrandt, E and Doffonchio, D (2001). Biodiversity of Goedermatorphilacaa isolated from altered stones and monument in the Mediterranean basi. Environmental Microbiology. 3;471-479.

Wired chemist: www.wiredchemist.com. Chemistry.

Yan, F., Ge Q.Y, Li Q. Yu M., zhu, X.D. and pan J. (2012). Analysis of Microbial community on the surface of the histonic stone and nearby rock sample in Yun gang. Acta Microbiology Sin 52 (5): 629636.

\section{How to cite this article:}

Etim, Lawrence Bassey. 2019. Microbial Ecological Dynamics, Load and Diversity of Sculptured Artworks in Cross River University of Technology Outdoor Gallary. Int.J.Curr.Microbiol.App.Sci. 8(10): 2550-2557. doi: https://doi.org/10.20546/ijcmas.2019.810.295 